\title{
PENGGUNAAN KONSEP REDESAIN TERHADAP GELANGGANG REMAJA SEBAGAI TEMPAT KETIGA DI KAWASAN BULUNGAN, JAKARTA SELATAN
}

\author{
I Dewa Nyoman Artha ${ }^{1)}$, Nina Carina ${ }^{2)}$ \\ 1) Program Studi S1 Arsitektur, Fakultas Teknik Universitas Tarumanagara, dewanyoman11@gmail.com \\ 2)Program Studi S1 Arsitektur, Fakultas Teknik, Universitas Tarumanagara,ninac@ft.untar.ac.id
}

\begin{abstract}
Abstrak
Kawasan Bulungan, Jakarta Selatan merupakan kawasan yang sangat ramai dan dipenuhi oleh anak muda setiap harinya. Keberadaan bangunan-bangunan komersial dan sekolah menjadi sumber keramaian di kawasan Bulungan. Pada malam hari, pedagang Gulai Tikungan menjadi salah satu karakter kuat yang menjadi pemikat keramaian di kawasan ini dan kawasan ini dapat menjadi sebuah Third Place bagi masyarakat. Gelanggang Remaja Bulungan (GRB) memiliki potensi dijadikan sebuah Third Place, tetapi desain eksisting GRB kurang mewadahi kebutuhan untuk menjadi third place bagi anak-anak muda saat ini. Tata letak bangunan dan ruang publiknya membuat kesan ekslusif karena seolah hanya mewadahi aktivitas kelompok remaja tertentu di bidang seni dan olahraga. Redesain GRB perlu dilakukan agar sesuai sebagai Third Place yang memiliki ciri anak muda dari semua kalangan saat ini. Penggunaan konsep redesain digunakan dengan tujuan mempertahankan memori akan bangunan lama, karena GRB merupakan bangunan yang bersejarah sebagai Gelanggang Remaja pertama di Indonesia dan memiliki hubungan kuat dengan komunitas yang sudah ada sejak tahun 80an yakni Kelompok Penyanyi Jalanan (KPJ). Kegiatan pentas seni, keberadaan kafe, relokasi gulai tikungan (gultik) ke dalam tapak akan menjadi pemikat. Sirkulasi yang mudah dengan keberadaaan grand ramp serta pengalaman ruang menarik diharapkan dapat meningkatkan minat anak muda dalam mengeksplor tempat ini.
\end{abstract}

Kata Kunci: Gelanggang Remaja Bulungan; Gulai Tikungan; Redesain

\begin{abstract}
Bulungan Area, South Jakarta is a very busy area that is always crowd with young people everyday. There are commercial buildings and schools which are a source of crowd in Bulungan area. At night, Beef Curry Rice at Junction (Gultik) become one of the strong characters who create crowds in Bulungan area. Bulungan Youth Arena (GRB) has the potential to become a Third Place, but the existing GRB's design does not accommodate the requirement to become a third place for young people now. The layout of GRB's public space makes an exclusive impression because GRB seems to accommodate only arts and sports youth activities. Redesign GRB needs to be done to become the Third Place that has the characteristics of the times and young people from different circle can interact comfortably. The use of the redesign concept is used with the aim of preserving the old memory of GRB, because GRB is a historic building as the first Youth Arena in Indonesia and has a strong relationship with the community that has existed since the $80 \mathrm{~s}$, the community is Kelompok Penyanyi Jalanan (KPJ). Performing arts activities, the existence of cafes, relocation of Beef Curry Rice at Junction (gultik) into the site will be inviting more people to come in. The existence of a grand ramp make circulation be easier and interesting space experiences are expected to increase the interest of young people in exploring GRB.
\end{abstract}

Keywords: Beef Curry Rice, Bulungan Youth Arena; Redesign 


\section{PENDAHULUAN}

\section{Latar Belakang}

Kawasan Bulungan, Jakarta Selatan merupakan sebuah Kawasan yang semakin semarak saat ini. Kemudahan aksesibilitas membuat banyak masyarakat sering berkunjung ke kawasan tersebut untuk berekreasi, mencari makanan, mencari hiburan, dan berbelanja. Salah satu yang menarik dari Bulungan selain dari pengunjung nya yang sangat ramai adalah Komunitas lokalnya. Banyak komunitas-komunitas anak muda yang terdapat di Kawasan Bulungan, tepatnya di Gelanggang Remaja Bulungan (GRB) yang sudah berdiri sejak 16 April 1970. Disana terdapat komunitas basket, futsal, bulutangkis, voli serta pertunjukkan teater, dan di depan terdapat warung apresiasi sebagai tempat kumpul dari Kelompok Penyanyi Jalanan (KPJ). Dengan banyak nya para komunitas yang ada ini menjadi sebuah tantangan bagaimana ruang publik atau proyek yang direncanakan dapat mewadahi mereka tanpa menghilangkan minat masyarakat lain untuk datang. GRB yang sudah tua memang masih bisa digunakan dan cukup aktif setiap hari nya, namun desain bangunan nya formal dan tertutup bahkan terkesan ekslusif karena hanya mewadahi kegiatan olahraga dan seni saja.

Menurut Ching (1979), bahwa arsitektur dalam menggabungkan bentuk dan ruang menjadi satu inti pokok, tidak hanya memperlancar tujuan, tetapi menunjukkan arti. Seni arsitektur membuat keberadaan kita tidak saja tampak, tetapi penuh arti. Dengan begitu dibutuhkan Redesain GRB terutama untuk area Gedung Pertunjukan dan sekitarnya. Tujuan nya adalah berfokus pada seluruh masyarakat pengguna Bulungan seperti anak-anak muda dan juga komunitas lokal yang ada, sehingga bangunan ini menjadi tempat yang lebih inklusif dan tentunya bersifat playful serta mudah dijangkau masyarakat luar. Penggunaan konsep redesain dalam mengubah GRB menjadi Third place, dikarenakan GRB merupakan bangunan yang bersejarah sebagai gelanggang remaja pertama di Indonesia dan memiliki hubungan yang sangat kuat dengan komunitas yang berdiri sejak tahun 80an yakni Kelompok Penyanyi Jalanan (KPJ). KPJ telah menorehkan banyak prestasi di bidang seni serta olahraga dan melahirkan seniman-seniman untuk Indonesia sampai saat ini. Konsep redesain diharapkan dapat mempertahankan memori akan bangunan lama dan mempertahankan ciri lokal dari GRB di saat pembangunan ke arah modern semakin pesat di wilayah Kebayoran Baru, Jakarta Selatan. Program-program yang masih diminati komunitas lokal tetap dipertahankan. Perubahan program akan dilakukan dengan mengubah besaran kapasitas dan sifat ruang nya menjadi lebih terbuka sesuai dengan jaman saat ini.

\section{Rumusan Masalah}

a. Bagaimana Redesain GRB bisa mewadahi semua masyarakat dan komunitas yang ada?

b. Apa program yang tepat untuk Redesain GRB merespon perubahan jaman?

c. Bagaimana Redesain GRB bisa menjadi Third Place bagi anak muda di kawasan Bulungan?

\section{Tujuan dan Manfaat}

a. Mengubah Gelanggang Remaja Bulungan menjadi Third Place untuk anak-anak muda di Kawasan Bulungan, dengan mempertahankan karakter kawasan yang sudah ada dan bersifat lebih inklusif untuk semua masyarakat.

b. Memahami penggunaan konsep redesain yang tepat dengan melihat aspek-aspek yang perlu diperhatikan.

\section{Ruang Lingkup}

a. Sasaran Pengguna: Masyarakat Kramat Pela, Komunitas Teater, Komunitas Olahraga, Kelompok Penyanyi Jalanan (KPJ), dan komuter.

b. Bangunan yang diredesain: Gedung Pertunjukkan, Gedung BCD, Warung Apresiasi, deretan warung di depan Blok M Plaza, Panggung Terbuka, dan Taman Kelompok Penyanyi Jalanan. 
c. Kawasan yang didesain: Sebagian Kawasan Gelanggang Remaja Bulungan, Area Jalur Pedestrian di depan Kawasan yang di redesain terutama yang digunakan oleh pedagang gulai untuk berjualan dan sebagai tempat parkir liar kendaraan.

\section{KAJIAN LITERATUR}

\section{Redesain dalam Arsitektur}

Dalam Arsitektur, redesain terdiri dari 2 kata bahasa inggris yaitu re dan design. Penggunaan kata re mengacu pada pengulangan atau melakukan kembali, sehingga redesain dapat diartikan sebagai mendesain ulang. Menurut American Heritage Dictionary (2006) "Redesign mean to make a revision in the appearance or function of", yang dapat diartikan membuat revisi dalam bentuk desain atau program. Menurut Hanks (2009), "Redesign is to change the design of (something)", yang dapat diartikan mengubah desain dari (sesuatu). Menurut John et al. (1990), redesain adalah membangun dan merancang kembali suatu bangunan sehingga terjadi perubahan bentuk tanpa merubah fungsinya baik melalui perluasan, perubahan maupun pengaturan tata letak letak. Heinz et al. (2007), mengartikan kata-kata membangun kembali dengan membongkar secara seksama dan atau memperbaiki kekurangan dari bangunan yang telah ada. Ferina (2012) menyatakan, dari beberapa definisi di atas dapat disimpulkan bahwa redesain mengandung pengertian yaitu merancang kembali suatu objek yang telah ada, sehingga terjadi perubahan penampilan baru pada objek tersebut.

Dalam dunia arsitektur, merancang kembali sama halnya dengan membangkitkan kembali karya arsitektur yang sudah ada namun belum termanfaatkan dengan baik atau mulai kurang tepat guna seiring perubahan zaman. Merancang kembali identik dengan meneliti kekurangan bangunan baik arsitektural maupun non-arsitektural dan kemudian memperbaikinya melalui rancangan baru, sehingga dengan adanya perancancangan baru ini diharapkan dapat menyelesaikan masalah yang ada dan bangunan dapat berfungsi sesuai dengan perkembangan zaman di lingkungan nya. Redesain dalam arsitektur dapat dilakukan dengan melakukan penambahan unsur pada suatu bangunan, baik itu mengurangi atau menambahkan. Dalam melakukan redesain pada bangunan biasanya merupakan bangunan heritage, dimana bangunan memiliki usia minimal berumur 50 tahun.

Berikut beberapa kriteria yang menjadi dasar sebuah bangunan disebut sebagai sebuah heritage: (1) Kriteria Estetika atau keindahan, yaitu yang berkaitan dengan keindahan secara komposisi, irama, kesatuan, dan keseimbangan; (2) Kriteria kekhasan, yaitu bangunanbangunan yang memiliki karakter kuat dari kelas atau jenis bangunan tertentu; (3) Kriteria kelangkaan, yaitu kriteria yang merupakan bangunan terakhir yang tersisa atau merupakan peninggalan terakhir dari gaya yang mewakili zaman nya; (4) Kriteria keluarbiasaan, yaitu kriteria yang dilihat berdasarkan bangunan yang paling menonjol, terlihat dari besar, bentuk dan sebagainya; (5) Kriteria Peran Sejarah, yaitu kriteria berdasarkan peran dimana sebuah bangunan mempunyai peran dalam peristiwa-peristiwa terdahulu dan memiliki ikatan simbolis antara peristiwa yang lalu dengan peristiwa yang ada sekarang (Ardiani, 2009). Dari kriteriakriteria tersebut, maka diperoleh bangunan-bangunan mana saja yang dilakukan pelestarian atau dirancang kembali dengan mempertahankan aspek-aspek pentingnya. Redesain juga harus memperhatikan faktor sosial yang ada di lingkungan sekitar, agar bangunan tersebut setelah selesai dilakukan dapat memenuhi tujuannya dan dirasakan manfaatnya oleh lingkungan sekitar. Dan bukan sebaliknya, setelah dilakukan bangunan tersebut malah tidak diminati lagi atau malah merusak citra lingkungan sekitar atau merugikan bangunan-bangunan lama yang ada di lingkungan sekitar. 


\section{Third Place}

Menurut Oldenburg (1989), hal yang paling efektif untuk membangun sebuah komunitas adalah melihat sebuah tempat dimana masyarakat bisa dengan mudah saling berhubungan secara rutin. Kemudian mereka dilayani dengan menganggap setara status sosial masingmasing. Percakapan yang bersifat informal merupakan aktivtas dominan dan terpenting dalam membangun sebuah komunitas yang baik di sebuah ruang publik. Menurut Oldenburg (1989), Third Place dibagi menjadi beberapa syarat:

\section{a. Neutral}

Yang berarti mereka bebas pergi dan datang kapan saja tanpa adanya hukuman. Dan jika mereka tidak datang 2 atau beberapa minggu ke tempat itu, mereka akan merasa semakin tertarik dan antusias untuk berkunjung ke tempat itu.

b. Level

Perbedaan status yang di tempat lain sangat diperhatikan, di tempat ini diabaikan. Tidak ada yang menjadi tuan rumah di sini. Semua dipandang memiliki status sosil yang sama.

c. Percakapan

Dengan bercakap-cakap kita bisa menghilangkan rasa bosan. Percakapan menjadi sebuah aktivitas utama di tempat ini. Tentunya percakapan yang menyenangkan tanpa membahas hal-hal politik atau agama ke dalamnya.

d. Akses mudah

Mereka memiliki kesempatan untuk berlama-lama dan mudah untuk ke tempat ini. Dengan begitu komunitas sekitar dapat dengan nyaman menikmati tempat.

e. Regular

Dimana orang baru dapat diterima, bukan secara otomatis tapi dapat dengan mudah diterima. Sehingga tidak ada rasa enggan untuk datang ke sini sendiri.

f. Tidak megah

Kesederhanaan untuk menarik golongan apapun datang ke tempat ini

g. Playful

Suasana dominan yang harus ditunjukkan di tempat ini adalah menyenangkan dan menghibur. Sekaligus menghilangkan rasa jenuh dan tegang terhadap kehidupan seharihari kita yang terkadang menimbulkan emosi dan Lelah.

h. A Home away from home

Sebuah ruang publik yang memberikan kenyamanan, mengembalikan semangat, dan menciptakan energi baru yang serupa dengan berada di rumah.

Seiring perkembangan zaman, para arsitek tidak hanya fokus dalam membangun hunian yang nyaman untuk tempat tinggal, namun pembangunan third place untuk lingkungan semakin ramai dibahas sebagai tempat masyarakat berinteraksi setelah berutinitas. Akan tetapi dalam pembangunan third place tidak hanya arsitek yang berperan, masyarakat juga ikut membangun dan berkontribusi. Seperti yang dikatakan Brendan Crain dalam jurnalnya yang berjudul 'Get Out of the Way', ia berpendapat 'to creare a great third place, one of the most important principles is to let users make it their own' dimana artinya untuk membuat sebuah tempat komunitas, komunitas itu sendiri yang harus terlibat (Crain, 2013). Kunci utama dari sebuah keberhasilan third place adalah pengelolaannya dimana masyarakat penggunanya yang mengelola. Dengan demikian, third place dibuat berdasarkan keinginan dan kebutuhan masyarakat yang menggunakannya (Halim, 2020).

\section{Kontekstual dalam Arsitektur}

Brolin (1980) menjabarkan, Kontekstualisme adalah kemungkinan mendesain bangunan dan keinginan menghubungkan bangunan baru dengan citra lingkungan sekitarnya. Seorang arsitek dianjurkan untuk memperhatikan dan kondisi lingkungan sekitarnya, mengutamakan kesatuan visual antara bangunan baru dengan bangunan lama, landmark, bahkan ciri arsitektur setempat yang keberadaannya telah diakui oleh masyarakat setempat. Sedangkan menurut Bill 
Raun, Kontekstual menekankan bahwa sebuah bangunan harus mempunyai hubungan dengan lingkungan dan bangunan sekitar. Keterkaitan tersebut membentuk sebuah proses yang menghidupkan kembali jiwa atau roh yang ada dalam lingkungan (bangunan lama) ke dalam bangunan baru yang akan dirancang. Dalam pemikiran kontekstual, kehadiran bentuk bangunan tidak diambil sesuai keinginan perancang, tetapi berdasarkan bentuk yang telah diakui oleh masyarakat setempat. Prinsip ini menyatakan pengertian bahwa kehadiran suatu bentuk merupakan pengembangan atau variasi dari suatu kondisi yang telah mapan sebelumnya.

Antoniades (1990) menjelaskan, kontekstual merupakan klasifikasi dari bidang konteks dalam arsitektur yang dapat berkaitan dengan tapak dari kawasan, lingkungan sekitar, kondisi bangunan sekitar, budaya, material, dan masyakarat setempat. Tujuanya untuk mengarahkan desain ke dalam suatu perancangan desain. Fungsi penggunaan pendekatan Arsitektur Kontekstual adalah: (1) untuk menghadirkan bangunan yang mempertimbangkan kondisi sekitarnya sehingga keberadaannya membentuk kesatuan dan dengan demikian potensi dalam kawasan tersebut sangat diperhatikan; (2) Membentuk sebuah citra yang bisa dinikmati oleh pengamat dalam suatu kawasan, yang terbentuk dari suatu komposisi banguna; (3) Kesatuan citra pengamat, yang terbentuk karena komposisi bangunan yang dilihatnya memiliki hubungan, meskipun keberadaannya tidak dibangun bersamaan. Arsitektur kontekstual seringkali berhubungan dengan kesadaran penghuninya terhadap lingkungan dan budaya setempat (Radoine,2017). Arsitektur dan konteks kehidupan kota, yang berisi kajian karakteristik sosial, ekonomi, dan fisik lingkungan kota dalam kaitannya dengan desain arsitektur. Arsitektur, sebagai objek yang tidak berdiri sendiri, melainkan membentuk kesatuan dengan sekitarnya, menjadi jaringan sosial yang satu, maupun lingkungan yang menjadi tumpuan kehidupan urban. Demikian juga dengan arsitektur kota, yang merupakan jaringan, komposisi ruang dan bangunan yang bertumpuk dalam waktu berbeda dan irisan berbagai permasalahan. Beberapa elemen dirubah, dihilangkan, diganti, ditimpa atau disandingkan dengan elemen baru dan.

Calthorpe (2001) menjabarkan asas yang disebut sebagai Principle of Diversity, Conservation, and Human Scale; bahwa, "These alternative principles apply equally to the social, economic, and physical dimensions of communities. For the example, the social implications of human scale may mean more police officers walking a beat rather than hovering overhead in a helicopter; the economic implications of human scale may mean economic policies that support small local business rather than major industries and corporations, and the physical implication of human scale may be realized in the form and detail of building as they relate to street." Sehingga dapat kita simpulkan bahwa asas-asas ini dapat mengajarkan tentang dasar-dasar dan etika dalam melakukan arsitektur secara kawasan dan lingkungan sekitar. Arsitektur kontekstual dalam proses pembentukan desain, berisi analisis dan pencarian konsep desain yang berbeda dan memperlihatkan hubungan antara bentuk bangunan dan konteks lingkungan perkotaan. Banyak orang menganggap kontekstualisme hanya menemukan kesamaan bangunan lama dan meniru nya sehingga terlihat bangunan baru memiliki kemiripan dengan bangunan lama atau hanya untuk mendorong langgam ciri arsitektur tertentu untuk dikenal masyarakat luar (Nurdin, 2012). Ada beberapa hal yang perlu diperhatikan dalam Arsitektur Kontekstual (Hantoro, 2017):

a. Bentuk dan persepsi arsitektur: Bentuk bangunan menunjukkan citra arsitektur yang kuat mengenai karakteristik lingkungan sekitarnya

b. Arsitektur sekitar: Arsitektur kontekstual tidak egois dan berusaha membentuk harmonisasi dengan arsitektur sekitarnya, walaupun bisa dibuat kontras dengan membawa beberapa elemen.

c. Fungsi konteks lingkungan sekitar: Fungsi dan program keseluruhan bangunan perlu 
memperhatikan kebutuhan konteks lingkungan sekitar agar dapat berjalan sesuai.

d. Estetika konteks: Estetika konteks harus tetap terlihat ke dalam desain arsitektur ke depan nya, walaupun tidak terlalu fokus kepada desain sendiri.

e. Pola keruangan dan pola peristiwa: Pola-pola ini adalah elemen dari budaya masyarakat lokal, ditemukan, disebarkan oleh budaya, dan termanifestasi dalam sebuah ruang (Alexander, 1979)

\section{Arsitektur yang merespon}

Bentley (1985) menyatakan, tujuh poin penting untuk desain yang responsif: (1) Permeability, penembusan yang transparan baik secara visual maupun akses; (2) Variety, keberagaman program dan ruang-ruang yang fleksibel; (3) Legibility, ciri atau karakter dari bangunan yang menonjol dan memperjelas orientasi; (4) Robustness, ada ruang-ruang fleksibel, dapat difungsikan untuk bermacam jenis aktivitas yang berbeda pada wakt-waktu tertentu; (5) Richness, kekayaan seni yang muncul dan pengalaman ruang melalui beragam material dan komposisi ruang; (6) Visual Appropriateness, dengan mudah dapat mengidentifikasi tipologi bangunan dengan hanya melihat luarnya, sekolah tampak seperti sekolah, rumah sakit seperti rumah sakit, mall seperti mall; (7) Personalization, membangun keterlibatan komunitas serta adanya percakapan antara manusia dengan alam.

\section{METODE}

\section{Metode Pengumpulan Data:}

Dalam metode pengumpulan data menggunakan metode rhythmananlisis dengan melakukan observasi lapangan. Proses yang dilakukan membutuhkan waktu lebih dari 7 hari. Pemilihan waktu dibagi menjadi empat, yakni siang weekend, siang weekdays, malam weekend, dan malam weekdays. Waktu yang dipilih didasarkan dari kemungkinan intensitas yang tinggi terjadi pada tapak sekitar. Dalam menjalankan proses ini bukan hanya mengamati saja, tetapi juga mewancarai narasumber seperti Anggota KPJ (Kelompok Penyanyi Jalanan) dan anak-anak sekolah. Metode ini dilakukan untuk mendapatkan data-data dan gambaran pada tapak dan kemudian akan mendapatkan sintesis yang akan digunakan dalam proses perancangan. Metode Rhytmanalisis ditujukan untuk mengetahui hubungan ruang dan waktu. Menurut Levebfre (1974), Pada ruang yang sama dengan waktu berbeda akan memiliki aktivitasaktivitas yang berbeda.

\section{Metode Perancangan:}

Untuk merespon tujuan dari redesain, dalam perancangan menggunakan metode kontekstual dengan metode tersebut dilakukan observasi lapangan untuk melihat bangunan-bangunan yang ada di sekitar. Dengan metode kontekstual bisa didapatkan bangunan yang ramah dengan lingkungan sekitarnya dan tetap menyesuaikan dengan perkembangan zaman.

\section{DISKUSI DAN HASIL}

\section{Penggunaan Konsep Redesain GRB}

Tidak semua bangunan mesti dilakukan redesain atau bahkan bisa diredesain. Ini dikarenakan ada faktor kebutuhan dari lingkungan sekitar dan apakah bangunan cukup layak untuk dipertahankan keberadaan nya di lingkungan nya. Ada 4 hal yang mendasari kenapa bangunan ini mesti diredesain dan bukan di bangun menjadi proyek third place yang baru tanpa memperhatikan bangunan lama: (1) Penampilan tertutup dan kurang menarik remaja, penampilan GRB saat ini amat tertutup secara desain dengan adanya pagar-pagar di depan dan dinding masif yang sangat mendominasi pada fasad setiap bangunan. Bangunan yang secara visual sudah sangat tua, bahkan terkesan seram bagi anak-anak muda saat ini; (2) Tidak sesuai dengan millenial lifestyle saat ini, dari bentukan massa bangunan terlihat sangat formal dan kurang ekspresif untuk digunakan anak-anak muda. Unsur Open Architecture pada bangunan 
ini sangat kurang. Ada massa bangunan yang memblok sehingga memisahkan aktivitasaktivitas yang seharusnya bisa lebih menyatu; (3) Berpotensi Menjadi Third Place untuk komunitas sekitar, di Kawasan ini sangat ramai pada malam hari setelah anak-anak muda selesai beraktivitas sekolah, kuliah, maupun kerja. Melakukan kegiatan seni, olahraga ataupun sembari nongkrong dan bercakap. Berada diantara SMAN 70, SMAN 6, Restoran-restoran, dan Pusat perbelanjaan Blok M Plaza; (4) Memiliki memori peristiwa sejarah yang sangat kuat, GRB merupakan sebuah tempat bernaung nya KPJ yakni para seniman anak jalanan. Di GRB pada tahun 70an lahir para seniman dan musisi hebat, dari seni tari hingga teater yang berhasil meraih juara di berbagai kompetisi. Tempat ini juga merupakan tempat para pelopor seni yang menjalin realasi di wilayah DKI Jakarta. Bukan hanya seni, penyair, pelukis dan atlit boxing juga lahir di sini. Anto Baret, Yoyik Lembayung, Mbah Surip, bahkan Iwan Fals berawal dari GRB. Karya-karya mereka berceritakan tentang kehidupan di Indonesia. Menurut Ardiani dalam buku Membangun Tanpa Merobohkan, menyatakan klasifikasi bangunan yang disebuh sebagai Heritage adalah kriteria kekhasan dan peran sejarah. Hal yang di sampaikan cocok dengan poin-poin Gelanggang Remaja Bulungan yang disebutkan di atas.

\section{Analisa Tapak}

Pada Kawasan Bulungan telihat perbedaan yang sangat signifikan pada intensitas aktivitas yang ada di malam dan siang hari. Pada siang hari, aktivitas di kawasan Bulungan didominasi oleh aktivitas yang berada di dalam ruangan, seperti sekolah, berbelanja, berolahraga, atapun aktvitas makan siang. Pada malam hari, aktivitas semakin ramai, anak-anak muda sehabis pulang sekolah, kuliah ataupun kerja memadati ruang luar kawasan Bulungan. Mereka mengisi waktu senggang mereka untuk berinteraksi dengan teman-temannya dan menikmati keramaian kawasan Bulungan. Terdapat banyak sekali anak-anak yang sudah menjadikan kawasan ini sebagai tujuan mereka untuk melepas lelah sehabis melakukan rutinitasnya. Berikut adalah peta berdasarkan hasil observasi di kawasan Bulungan:

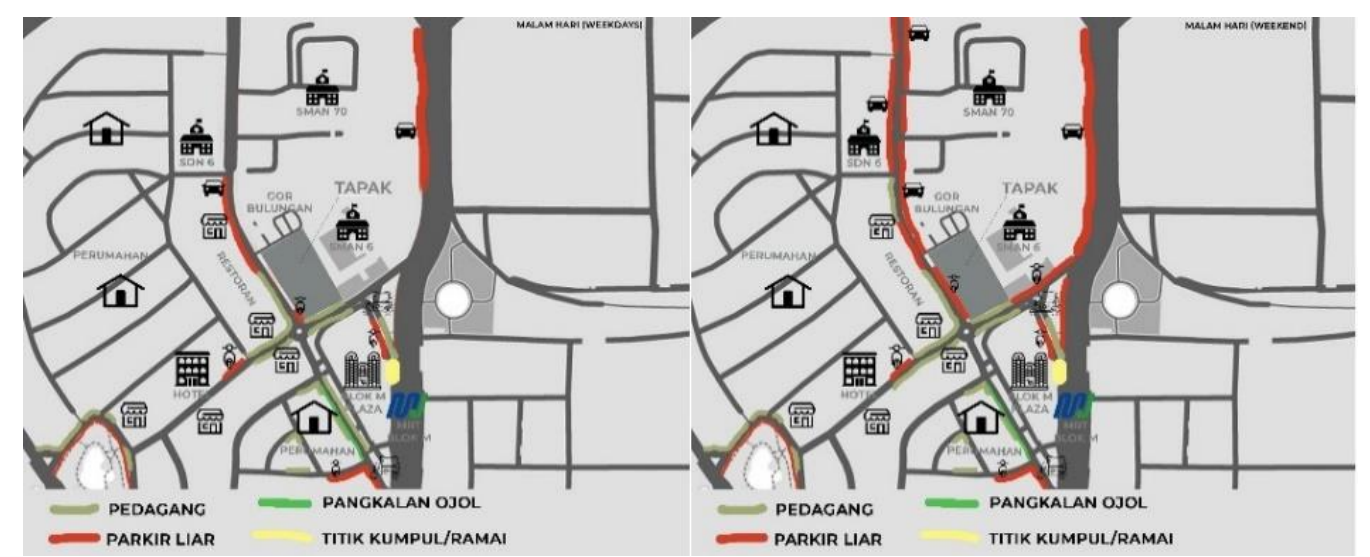

Gambar 1. Hasil Peta Keramaian Bulungan Malam hari Sumber: Penulis, 2020 


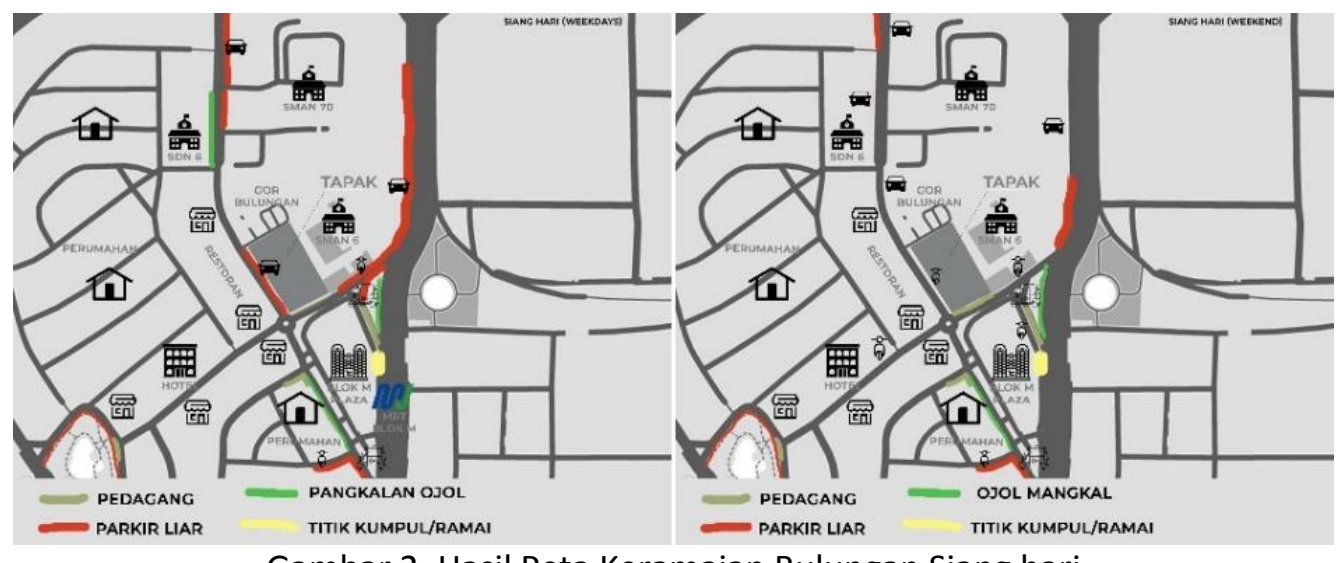

Gambar 2. Hasil Peta Keramaian Bulungan Siang hari

Sumber: Penulis, 2020

Berdasarkan peta keramaian Bulungan tersebut, didapatkan bahwa Kawasan Bulungan memiliki intensitas aktivitas tertinggi pada weekend di malam hari, dan pada weekdays di siang hari. Ini menunjukkan bahwa kawasan ini sangat fleksibel karena dapat menjadi second place pada siang hari dan third place pada malam hari. Kawasan Bulungan semakin berpotensi menjadi tempat ketiga karena merupakan kawasan TOD dari stasiun MRT Blok M. Hal ini membuat aksesibilitas yang mudah untuk para pekerja yang berkerja di daerah Bundaran $\mathrm{HI}$ dan akan pulang ke arah Lebak Bulus, karena Stasiun Blok M menjadi titik antara dari rute MRT fase 1 saat ini. Setelah melakukan observasi dan kemudian dianalisa mendapatkan sebuah pernyataan bahwa target pengguna di kawasan Bulungan adalah dominan anak muda.
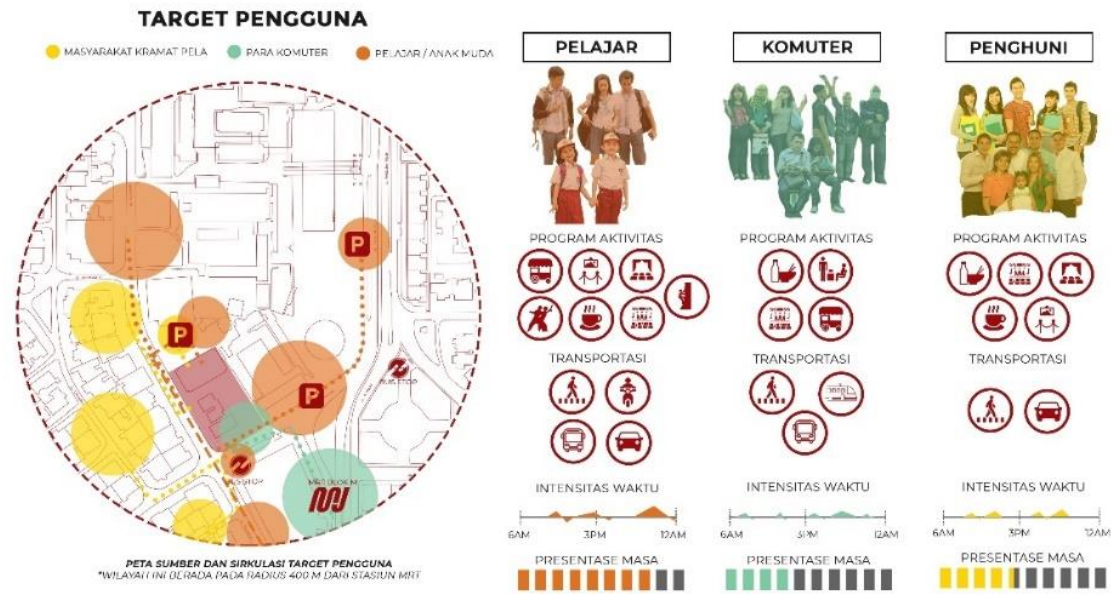

Gambar 3. Hasil Analisis Pengguna dan Aktivitas Kawasan Bulungan Sumber: Penulis, 2020

Dari hasil observasi dan analisa didapatkan aktivitas-aktivitas yang biasa dilakukan dan juga pengguna-pengguna yang biasa meramaikan kawasan Bulungan. Para pengguna merupakan anak muda yang didominasi pelajar, anak muda pekerja yang menjadi komuter, dan juga para penghuni di sekitar kawasan Bulungan. Aktivitas yang mereka lakukan cenderung ke kegiatan kuliner dan juga menikmati pentas seni yang ada, walaupun pentas seni yang ada bersifat tertutup karena berada di dalam gedung pertunjukkan. Gedung pertunjukkan ini terdapat di dalam kawasan Gelanggang Remaja Bulungan (GRB). Ada sesuatu yang unik dari gedung pertunjukkan yakni dari cat warna luarnya yang berbeda pada tiap bagian. 


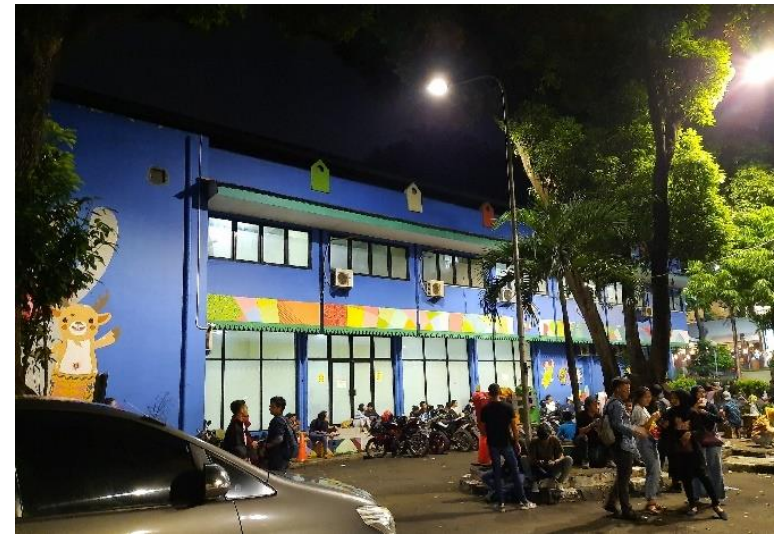

Gambar 4. Gedung Pertunjukkan Hadap GOR Bulungan Sumber: Dokumentasi Pribadi, 2020

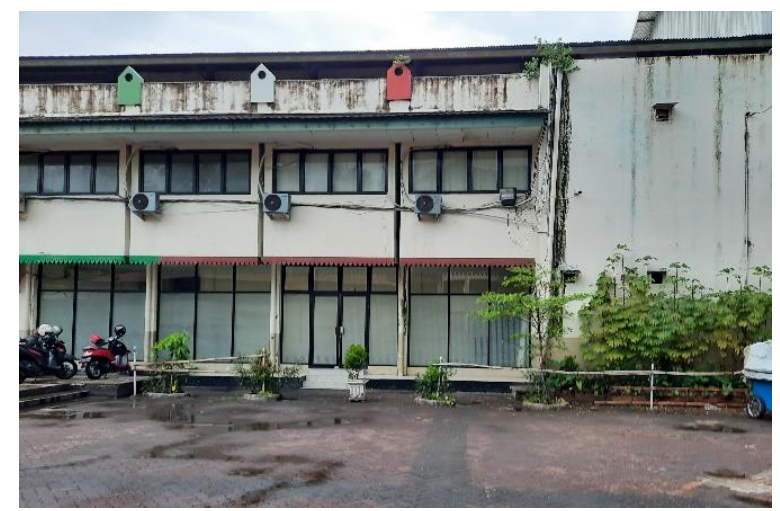

Gambar 5. Gedung Pertunjukkan Hadap Gedung Sanggar BCD Sumber: Dokumentasi Pribadi, 2020

Dengan demikian dapat disimpulkan bahwa renovasi pada GRB hanya dilakukan untuk mempersiapkan Asian Games 2018. Itu pun juga hanya dilakukan dengan mencat ulang pada Gedung Pertunjukkan sesuai tema Asian Games di bagian yang menghadap GOR Bulungan, sementara yang menghadap area Gedung Sanggar BCD tidak dicat ulang sama sekali. Ini salah satu yang menjadi faktor bahwa GRB mesti diredesain. Kesimpulan yang didapat dari Metode Ryhtmanalisis dan observasi ini adalah kawasan Bulungan sangat ramai dengan anak-anak muda dan sangat berpotensi menjadi pusat aktivitas anak muda Jakarta Selatan, tetapi kurangnya bangunan-bangunan yang mendukung aktivitas tersebut, terutama GRB yang berada di tengah kawasan Bulungan tetapi secara desain terkesan formal dan tertutup.

\section{Sejarah GRB}

Gelanggang Remaja Bulungan (GRB) didirikan pada tahun 1970 oleh Gubernur DKI Jakarta pada saat itu, yakni Ali Sadikin. GRB ini merupakan gelanggang remaja pertama di Jakarta bahkan di Indonesia. Bertujuan mewadahi bakat dan talenta remaja dalam bidang seni dan olahraga. Selain itu, Pembuatan GRB juga didasari oleh maraknya aksi tawuran yang terjadi di Jakarta Selatan. Sehingga Gubernur Ali Sadikin berharap pembuatan GRB dapat meredam aksi tawuran anak-anak SMA dengan mengalihkan nya ke kegiatan-kegiatan positif ke bidang seni dan olahraga. Pada tahun 70an, GRB berusaha untuk mengubah kesan seram Jakarta Selatan yang pada saat itu banyak sekali berkeliaran gangster-gangster. Pada saat itu GRB mulai melahirkan seniman-seniman hebat, sekaligus menjadi masa kejayaan dari GRB dalam menorehkan prestasi-prestasi di lomba kejuaraan seni di Jakarta. Dari sebatas seni lukis, ilustrasi, kaligrafi, menggambar dan sketsa, bertambah dengan kegiatan batik, tata ruang, tata panggung, desain grafis, fotografi, sampai multimedia. Kegiatan lain seperti symposium, seminar, dan lokakarya sering digelar. Pada era 90an terutama setelah era reformasi, para ketua seniman sudah tidak 
terlalu dekat dengan bawahan nya sehingga kesenian di GRB mulai menurun, wilayah GRB semakin komersial atau berbayar, dan diminati oleh hanya sanggar-sanggar komersial.

\section{Aspek-aspek dalam Redesain}

Redesain adalah Aktivitas melakukan pengubahan pembaharuan dengan berpatokan dari wujud desain yang lama kemudian diubah menjadi baru, sehingga dapat memenuhi tujuantujuan positif yang mengakibatkan kemajuan (Roshif, 2013). Redesain akan menjadi tujuan utama sehingga memori akan bangunan lama tidak hilang dan sekaligus mempertahankan ciri lokal pada bangunan. Ada 3 aspek yang perlu diperhatikan dalam melakukan redesain yakni sejarah, masa lalu, dan masa kini. Sejarah sebagai catatan masa lalu yang tertulis, mesti tetap dihadirkan di proyek redesain. Masa lalu, sebagai peristiwa-peristiwa penting yang membangun karakter sebuah proyek mesti dihadirkan di proyek ini. Kemudian Masa kini, sebagai faktor untuk menyesuaikan zaman yang telah berbeda dan gaya hidup masyarakat kota yang sudah berubah mesti dihadirkan untuk merespon perubahan yang ada. Tiga aspek tersebut akan menjadi penentu desain, program, zoning, dan juga ciri dari arsitektur bangunan tersebut.

\section{Implementasi Konsep Redesain}

Dalam melaksanakan konsep redesain dibutuhkan pertimbangan besar terhadap sejarah, masa lalu, dan masa kini. Berikut implementasi nya terhadap Gelanggang Remaja Bulungan:

a. Sejarah, mempertahankan memori akan bangunan lama dengan mempertahankan letak panggung terbuka yang pernah dijadikan pentas seni akbar, dengan begitu panggung terbuka yang baru tetap mempertahankan peristiwa-peristiwa yang pernah terjadi pada area tersebut.
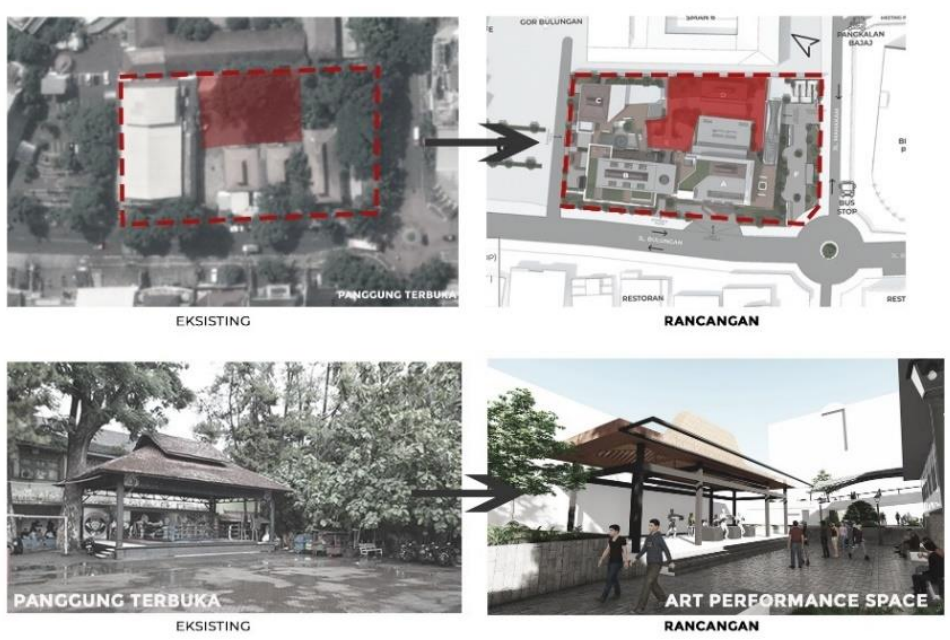

Gambar 6. Eksisting dan Hasil Rancangan dari Letak dan Bentuk Panggung Terbuka Sumber: Penulis, 2020

b. Masa lalu, mempertahankan program-program dan ciri arsitektur bangunan eksisting yang masih dimungkinkan aktif dengan mewadahi bakat remaja dalam bidang seni dan olahraga dan mempertahankan karakter atap eksisting. Program-program eksisting yang dipertahankan adalah Area Panjat Tebing, Sanggar Tari, Boxing Camp, Warung makan, dan Ruang pertunjukkan teater.

c. Masa kini, menyesuaikan unsur yang ada pada masa lalu ke masa kini sehingga dapat menarik minat pengunjung untuk hadir dan datang dengan kehadiran sesuatu yang baru dan inovatif. Salah satunya adalah dengan menghadirkan kafe dan merelokasi gulai tikungan ke dalam tapak yang merupakan salah satu karakter kuat dari Bulungan. Kemudian ada sebuah program edukasi untuk merespon anak-anak sekolah zaman sekarang dalam bentuk perpustakaan digital yang menghadirkan pengetahuan dari 
berbagai sumber digital, seperti rekaman suara, video, musik, dan sebagainya.
I ART CULTURAL
I CULINARY

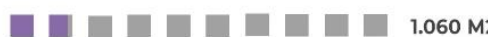
I EDUCATION

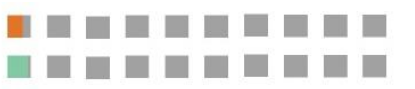
$420 \mathrm{M} 2$
I OTHERS
口 व
| SPORTS
TOTAL

Gambar 7. Presentase Program Hasil Redesain GRB

Sumber: Penulis, 2020

Gelanggang Remaja Bulungan memiliki atap yang khas pada zaman nya, hal ini menjadi perhatian dan merupakan salah satu karakter kuat pada bangunan eksisting, maka dari itu dibutuhkan sebuah konsep yang bisa memodifikasi atap GRB eksisting dengan tetap mempertahankan jiwanya. Maka dari itu Konsep Arsitektur Nusantara digunakan untuk menambah impresi dari wujud lama bangunan GRB yang bersejarah dan khas pada zaman nya.

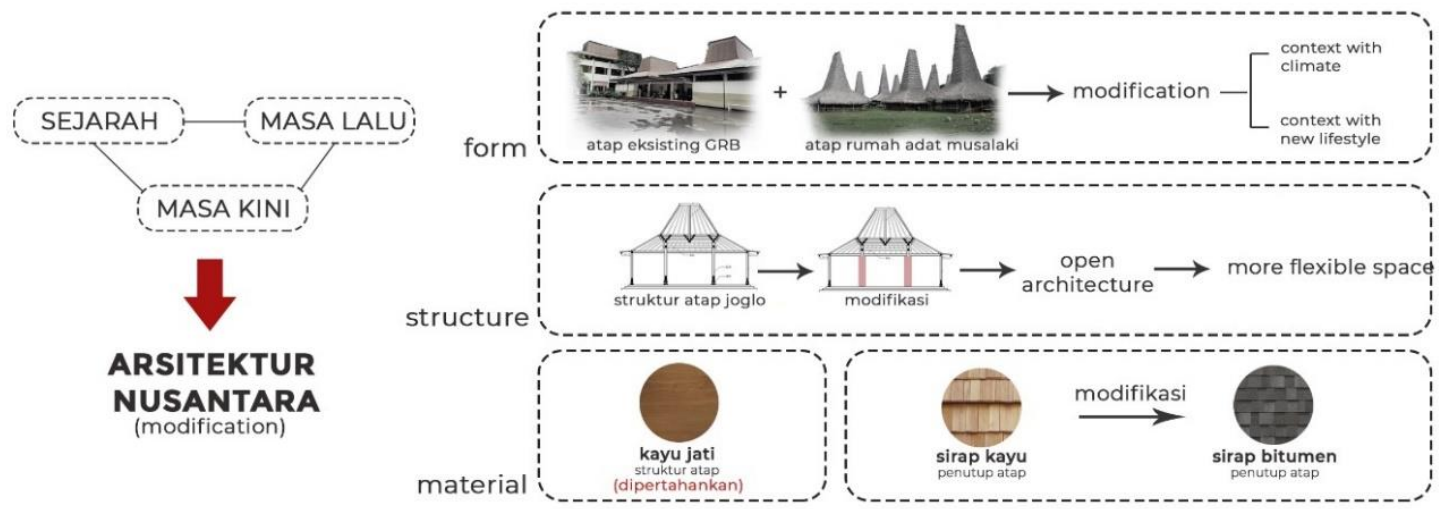

Gambar 8. Penjelasan Konsep Arsitektur Nusantara

Sumber: Penulis, 2020

Arsitektur Nusantara dalam bekerja menambah impresi mempengaruhi 3 hal dalam memodifikasi atap eksisting GRB : (1) Bentuk, Bentuk mengkombinasikan atap eksisting dengan rumah adat asal NTT yang memiliki kesamaan komposisi sehingga dapat dikombinasi dengan mudah, dengan hal ini dapat memberikan kesesuai dengan iklim dan juga gaya masa kini; (2) Struktur, Dalam hal truktur diambil struktur atap joglo yang khas kemudian, soko yang berada di tengah ruang dihilangkan untuk membuat ruang menjadi lebih fleksibel namun tetap mencirikan atap nusantara dengan konstruksi atapnya yang khas; (3) Material, Material dalam hal ini yang dipertahankan adalah kayu jati sebagai material konstruksi yang khas dari atap Joglo. Sedangkan yang dimodifikasi adalah tampilan luarnya yakni penutup atap berbahan sirap kayu yang diganti dengan material sirap bitumen yang lebih kuat dan fleksibel dari segi penggunaan sudut kemiringan atap.

\section{Redesain Menjadi Tempat Ketiga}

Dalam memenuhi kriteria sebagai tempat ketiga ada beberapa hal yang harus diaplikasikan ke dalam proyek redesain GRB ini. Hal-hal tersebut diaplikasikan ke dalam suasana ruang dan pengalaman ruang yang terbentuk. Hal ini akan menjadi poin penting dalam membentuk karakter tempat ketiga untuk anak muda zaman sekarang walaupun dari segi visual proyek redesain ini masih cenderung mempertahankan wujud aslinya. Dalam menentukan poin penting yang mesti diaplikasikan saya menggunakan metode kontekstual terhadap lingkungan sekitar dan target pengguna untuk menentukan nya. Berikut adalah 6 poin penting yang diaplikasikan ke dalam proyek: (1) Connector Corridor, koridor ini digunakan untuk memberikan sekuens luas-sempit dan gelap terang di lantai dua. Bermula dari Grand Ramp Entrance yang merupakan sumber pengunjung terbanyak. Ini berfungsi sebagai penghubung setiap massa dan ruangan di lantai dua. Pengalaman ruang menarik berjalan sekaligus menikmati keramaian Jalan Bulungan yang padat dari level yang lebih tinggi; (2) Open Theater, 
Konsep ini memiliki kefleksibelan yang cukup unik dengan berbagai alternatif jenis teater yang bisa ditampilkan, bahkan bisa juga digunakan untuk menonton film. Teater yang sangat fleksibel ini tentu merespon sifat anak-anak muda yang suka mencoba hal-hal baru yang positif danbersifat informal. Ketika tidak ada event ruang ini bisa digunakan untuk berkumpul; (3) Outdoor Ground Level, Area ruang luar pada level ground sangat dominan untuk merespon anak-anak muda yang suka menikmati ruang luar sembari berkumpul, bermain, dan menikmati pentas seni. Mempertahankan area ruang luar dan panggung terbuka yakni Art Performance Stage yang memberikan penampilan pentas seni secara semi outdoor. Area ini kan sangat ramai apalagi berada dekat dengan pintu masuk ke bawah tanah yang berisi Art Mural dan Multipurpose Event Space.

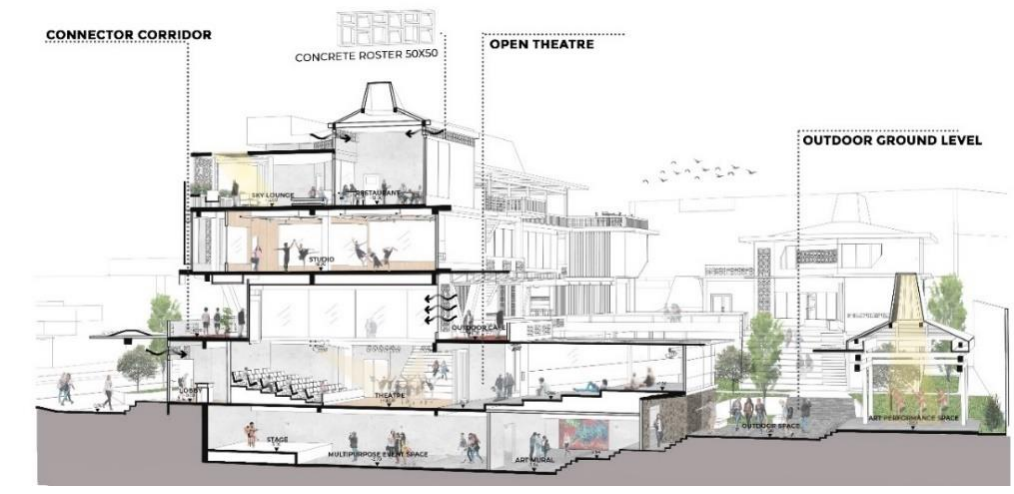

Gambar 9. Potongan Perspektif Art Cultural dan Panggung Terbuka Sumber: Penulis, 2020

(4) Open Plan, Konsep ini merupakan respon dari para anak muda yang senang menikmati suasana ruang luar sambil nongkrong. Menjadikan ruangan lebih luas dan tampak lebih ekspresif dengan mengekspos ruangan dan struktur. Dari luar bangunan para pengunjung bisa melihat aktivitas-aktivitas yang dilakukan anak-anak muda di dalam nya, begitu juga sebaliknya; (5) Rooftop as Public Space, Aksesibilitas yang mudah tanpa perlu masuk ke bangunan memungkinkan area level paling atas sebagai ruang publik. Roof Garden diisi dengan Music corner menjadi daya tarik bagi anak-anak muda untuk nongkrong dan bersantai sekaligus menikmati keramaian Kawasan Bulungan dari atas. Dari sini pengunjung bisa menikmati keindahan skyline kota Jakarta; (6) Food plaza, Ruang luar yang cukup dominan pada proyek ini diharapkan dapat dimanfaatkan untuk melakukan kegiatan kuliner dan juga rekreasi. Dengan disediakan nya tempat berdagang untuk pedagang informal, plaza ini dapat aktif dan ramai. Ini merupakan hasil dari relokasi pedagang gulai tikungan yang awalnya berjualan sembarang di jalur pedestrian.

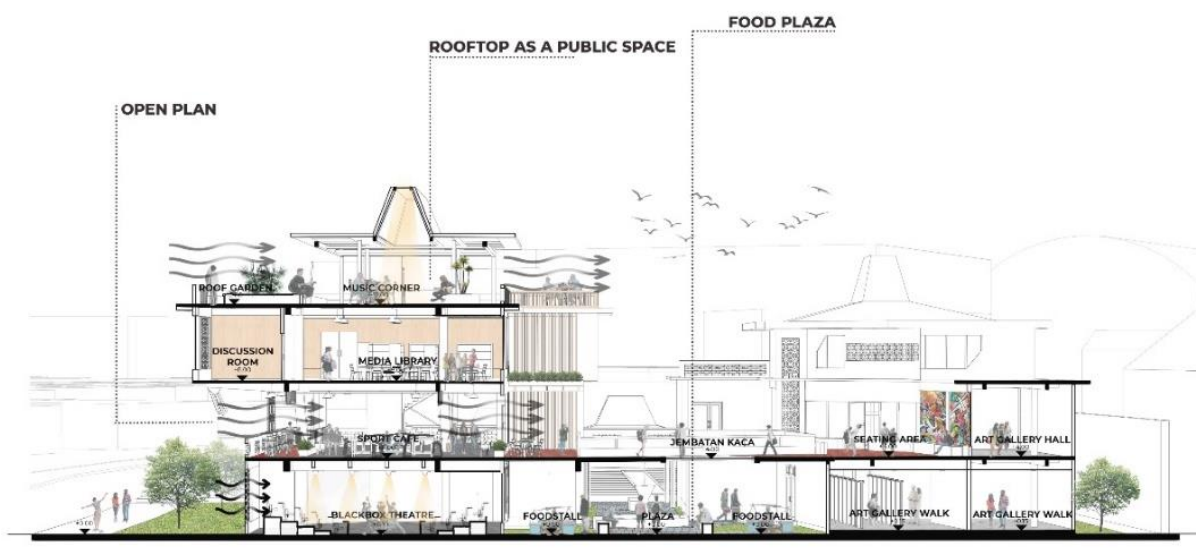

Gambar 10. Potongan Perspektif Art Education dan Art Community Sumber: Penulis, 2020 


\section{KESIMPULAN DAN SARAN \\ Kesimpulan}

Melakukan redesain berbeda dengan melakukan desain, dalam melakukan redesain banyak aspek-aspek yang perlu diketahui sebelumnya, seperti struktur, letak massa, zoning, program, dan peristiwa-peristiwa penting yang pernah terjadi di dalam bangunan eksisting. Aspek-aspek tersebut perlu dipertimbangkan dan dibawa ke dalam perancangan baru, walaupun tidak perlu semua. Pada proyek redesain GRB memiliki tujuan untuk mempertahankan memori akan bangunan lama dan ciri arsitektur lokalnya, namun tetap bisa mewadahi aktivitas-aktivitas baru anak muda zaman sekarang. Masyarakat Jakarta akan merasa bosan dengan arsitektur modern yang sudah mulai menjamur, sehingga arsitektur lokal patut dipelajari dan menjadi pilihan tempat untuk melepas bosan dan penat sesuai dengan tujuan sebuah Third Place.

\section{Saran}

Redesain masih dianggap sebelah mata, karena belum banyak proyek redesain yang dapat menghadirkan arsitektur yang fantastis pada zamannya. Hal ini yang perlu terus dikembangkan, dalam melakukan redesain bertujuan mendorong arsitektur lokal untuk tetap disukai oleh pasar atau masyarakat zaman sekarang. Pada saat ini globalisasi sudah masuk ke Indonesia, ini sebuah kesempatan untuk mendorong arsitektur lokal atau arsitektur nusantara menuju pasar internasional dengan beberapa modifikasi pada bentuk dan teknologi.

\section{REFRENSI}

Antoniades, A. C. (1990). Poetics of architecture: Theory of Design. New York : Van Nostrand Reinhold.

Ardiani, M. (2009). Insertion: Menambah Tanpa Merobohkan. Surabaya: Wastu Lanas Grafika.

Bentley, I. (1985). Responsive Environment. London: The Architectural Press.

Brolin, C. (1980). Architecture In Context: Fitting New Buildings with Old. New York: Van Nostrand Reinhold.

Calthrope, P. (2001). The Regional City. Publisher: Island Press; 2nd None.

Ching, F. D.K. (1979). Arsitektur: Bentuk - Ruang dan Susunannya, Penerbit Erlangga.

Crain, B. (2013). Get Out of the Way. Montclair: Shelterforce.

Ferina, F. (2012). Redesain Wisma Fajar Senayan. Diakses 3 Juli 2020, dari https://library.binus.ac.id/eColls/eThesisdoc/Bab2/2012-1-00690-AR\%20BAB\%22.pdf

Halim, C. (2020). Penataan Ulang Pasar Tradisional Muara Karang. Diakses 10 Juli 2020, dari https://journal.untar.ac.id/index.php/istupa/article/viewFile/6837/5464

Hanks, P. (2009). The Collins English Dictionary. Harpercollins. Glasgow.

Hantoro, C. (2017). Pusat Layanan Pariwisata di Semarang. Diakses 3 Juli 2020, dari http://repository.unika.ac.id/15431/6/13.11.0005\%20LTP\%20Eric\%20Christianto\%20Hant or $0 \% 20 \mathrm{BAB} \% 20 \mathrm{~V} . \mathrm{pdf}$

Heinz, F. \& Suskiyatno, B. (Eds). (2007). Dasar-dasar Arsitektur Ekologi seri 1. Semarang: Kansius yogyakarta.

John, M. Echols, \& Shadily, H. (Eds). (1990). Kamus Inggris Indonesia. Jakarta: Gramedia Pustaka Utama.

Levebfre, H. (1974). The Production of Space. New York: Horizon Press.

Nurdin, R. (2012). Studi Literatur Mengenai Arsitektur Kontekstual. Diunduh pada 19 Mei 2012, di https://arsitekturbicara.wordpress.com/2012/05/19/studi-literatur-mengenaiarsitektur-kontekstual/. (disarikan dari berbagai sumber)

Oldenburg, R. (1989). The Great Good Place. New York: Paragon House.

Radoine, H. (2017). Architecture in Context: Designing in the Middle East, First Edition. Diakses 3 Juli 2020, dari https://onlinelibrary.wiley.com/doi/boo k/10.1002/9781119173120

Roshif, A. (2013). Redesain Lembaga Pemasyarakatan kelas I Malang. Diakses 8 Juli 2020, dari http://etheses.uin-malang.ac.id/1319/6/08660049 Bab 2.pdBrent 
